Int. J. Dev. Biol. 52: 299-305 (2008)

doi: $10.1387 / \mathrm{ijdb} .072336 \mathrm{mc}$

\title{
CDK4 activity in mouse embryos expressing a single D-type cyclin
}

\author{
MARIA A. CIEMERYCH ${ }^{1,2, *}$, QUNYAN YU ${ }^{3, \#}$, KATARZYNA SZCZEPANSKA $^{1}$ and PIOTR SICINSKI ${ }^{3}$ \\ ${ }^{1}$ Department of Embryology and ${ }^{2}$ Department of Cytology, Institute of Zoology, Faculty of Biology, University of Warsaw, Warsaw, \\ Poland, ${ }^{3}$ Dana-Farber Cancer Institute, Harvard Medical School, Boston, USA
}

\begin{abstract}
D-type cyclins (D1, D2, and D3) are components of the cell cycle machinery. Their association with cyclin-dependent kinase 4 (CDK4) and CDK6 causes activation of these protein kinases and leads to phosphorylation and inactivation of the retinoblastoma protein, $\mathrm{pRb}$. Using embryos expressing single D-type cyclin ('cyclin D1-only', 'cyclin D2-only' and 'cyclin D3-only'), we tested whether each of D-type cyclin plays the same role in CDK activation and phosphorylation of $\mathrm{pRb}$ during mouse embryonic development. We found that the level of CDK4 activity was similar in wild-type embryos and those expressing only cyclin D3 or cyclin D2. However, we did not detect CDK4 activity in embryos expressing only cyclin D1, despite the fact that this cyclin was able to form complexes with CDK4 and p27 ${ }^{\mathrm{kip} 1}$ in wild-type as well as in mutant embryos. Analysis of the expression pattern of mRNA encoding cyclin D1 revealed that the expression of this RNA is regulated temporally during embryogenesis. These data and results from other laboratories indicate that cyclin D1-dependent CDK4 activity is dispensable for normal development of the mouse embryo.
\end{abstract}

KEY WORDS: mouse, embryogenesis, CDK4, cyclin D, p27kip1, retinoblastoma protein

\section{Introduction}

Mammalian cell cycle progression is governed by subsequent activation of several cyclin dependent kinases (CDKs) that requires their binding to specific regulatory subunits - cyclins. Each of the cell cycle phases requires synthesis and subsequent degradation of the specific subset of cyclins. First to be synthesized, in the response to mitogenic stimulation, are D-type cylins (cyclin D1, D2 and D3). In contrast to other cyclins, the levels of D-type cyclins do not oscillate during the cell cycle but their levels remain high as long as the mitogenic signals are present in the environment (Matsushime et al., 1991). Once synthesized Dtype cyclins bind and activate their catalytic subunits - CDK4 and CDK6. One of the major function attributed to active cyclin DCDK4/6 complexes is the phosphorylation and inactivation of pocket protein family members i.e. retinoblastoma tumor suppressor protein (pRb), p107 and p130. In their hypophosphorylated state pocket proteins bind and inactivate E2F transcription factors, thereby preventing expression of genes which products are necessary for initiation and progression of S-phase (Dimova and
Dyson, 2005). Another function of cyclin D-CDK4/6 complexes is linked to their ability to bind cell cycle inhibitors members of KIP/ CIP protein family such as p27 Kip1 and p21 Cip1 (La Baer et al., 1997; Geng et al., 2001; Tong and Pollard, 2001). Both inhibitors have been shown to block the action of cyclin E-CDK2 and cyclin A-CDK2 complexes (Vidal and Koff, 2000). However, they do not interfere with catalytic activity of cyclin D-CDK4/6. Moreover, they are required as assembly factors of these complexes (La Baer et al., 1997). Therefore, formation of cyclin D-CDK4/6 complexes causes redistribution of $\mathrm{p} 27^{\mathrm{Kip} 1}$ and $\mathrm{p} 21^{\mathrm{Cip} 1}$ and facilitates the activation of other CDKs. Both $\mathrm{pRb}$ inactivation and sequestration of cell cycle inhibitors represented mechanisms by which D-type cyclins could impinge on cell cycle progression.

Generation of mice lacking D-type cyclins allowed detailed analyses of the role of these proteins both in the cellular proliferation and embryonic development (Ciemerych and Sicinski 2005; Kozar and Sicinski 2004). In our previous studies, we character-

Abbreviations used in this paper: CDK, cyclin-dependent kinase; Rb, retinoblastoma.

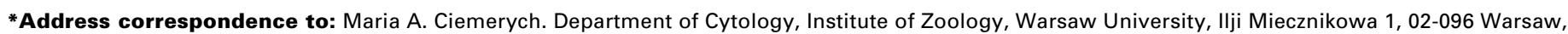
Poland. Fax: +48-2255-41210, 41203. e-mail: ciemerych@biol.uw.edu.pl http://www.biol.uw.edu.pl/cytologia

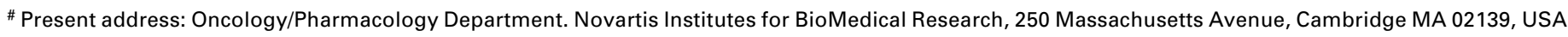

Published online: 14 February 2008

$0214-6282 / 2008 / \$ 35.00$

() UBC Press

Printed in Spain 
ized the phenotypes of 'single-cyclin' mice, i.e. animals expressing only cyclin D1, only cyclin D2 or only cyclin D3 (Ciemerych et al., 2002). Next, we generated mice lacking all three D-type cyclins. Analyses of these mice led to an unexpected finding. We observed that at least during embryonic development, cell proliferation and differentiation could occur in the absence of D-type cyclins (Kozar et al., 2004). Detailed molecular analyses revealed that in mouse embryonic fibroblasts lacking all three D-type cyclins, pRb was hypophosphorylated at the D cyclin-specific residues. Yet, lack of cyclin D-CDK4 activity did not prevent either phosphorylation of other $\mathrm{pRb}$ residues catalyzed by CDK2 or activation of transcription of E2F-dependent genes such as CDK1 or cyclin E (Kozar et al., 2004). Interestingly, phenotype of embryos lacking all three D-type cyclins resembled the phenotype of 'cyclin D1-only' animals (D2 $2^{-/-D 3^{-/-}}$).

Both D2/-D3/- and D1-/-D2-/-D3-/- mutant embryos died at $15.5-16.5$ day of development due to a severe anemia. The similarity of phenotypes of both mutant mice suggested that cyclin D1 might not play an essential function in cell cycle regulation during embryonic development. Therefore, we decided to take advantage of 'single-cyclin' mice and examine the ability of each D-type cyclin (including cyclin D1) to activate CDK4, drive $\mathrm{pRb}$ phosphorylation and form complexes with p2 $7^{\mathrm{kip} 1}$.

\section{Results}

\section{pRb is hypophosphorylated in embryos expressing only cyclin D1}

We previously generated mice lacking functional genes encoding two D-type cyclins i.e. $\mathrm{D} 1^{-/-} \mathrm{D} 2^{-/-}, \mathrm{D} 1^{-/-} \mathrm{D} 3^{-/-}$, and $\mathrm{D} 2^{-/-}$ $\mathrm{D}^{-/-}$(Ciemerych et al., 2002). We confirmed that organs of mutant embryos expressed solely one D-type cyclin i.e. cyclin D1 (D2 $\left.2^{-/-D} 3^{-/-}\right)$, or cyclin D2 (D1 $\left.1^{-/-D} 3^{-/-}\right)$, or cyclin D3 (D1 $\left.1^{-/-D} 2^{-/-}\right)$
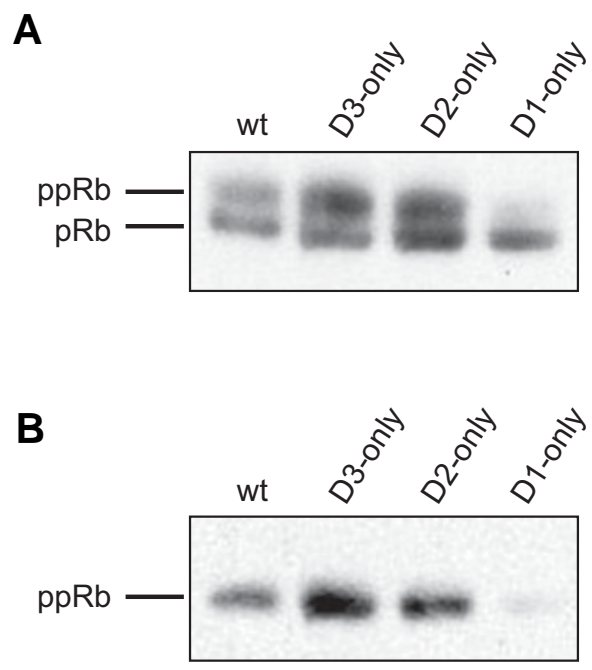

Fig. 1. pRb phosphorylation in wild-type and 'single-cyclin' embryos. Protein extracts were prepared from E13.5 embryos and subjected to Western blotting using: (A) antibodies specific for hypo- and hyperphosphorylated forms of $p R B$ and (B) antibody that recognizes $p R b$ phosphorylated at serine $807 / 811$ residues. ppRB denotes hyperphosphorylated $p R B$.
(Ciemerych et al., 2002). We also showed that CDK2 activity and DNA replication were detectable at similar levels in wild type and "single-cyclin" embryos (Ciemerych et al., 2002). However, at that time we did not test whether each of the D-type cyclin had the same capacity to activate CDK4 in vivo.

Retinoblastoma protein is one of the major substrates of cyclin D-CDK4 complexes and its phosphorylation status reflects CDK activity. Therefore, we gauged $p R b$ phosphorylation in wild type and 'single-cyclin' embryos. Protein extracts prepared from 'single-cyclin' and wildtype E13.5 embryos were subjected to the Western blot analysis, using a specific antibody that allows to distinguish hyper- and hypophosphorylated (slower-migrating) pRb species. Our analyses revealed that phosphorylated forms of $\mathrm{pRb}$ were clearly detectable in protein extracts obtained from wild type embryos and embryos expressing only cyclin D3 or only cyclin D2. In contrast, the phosphorylation of $\mathrm{pRb}$ was greatly diminished in embryos expressing only cyclin D1 (Fig. 1A). Next, we used phosphospecific antibody that recognizes $\mathrm{pRb}$ phosphorylated at serine $807 / 811$ at the residues that were previously shown to be phosphorylated exclusively by cyclin D-dependent kinases i.e. CDK4 or CDK6 (Zarkowska and Mittnacht, 1997). In wild type, 'cyclin D2-only' and 'cyclin D3-only' embryos, pRb was phosphorylated at serine $807 / 811$. However, phosphorylation of these residues was significantly diminished in 'cyclin D1only' embryos (Fig. 1B). These observations suggested decreased activity of CDK4 in "cyclin D1-only" embryos.

\section{CDK4 kinase activity is undetectable in embryos express- ing only cyclin D1}

Next, we tested directly CDK4 in protein extracts obtained from wild type and 'single-cyclin' embryos. First, we verified that the CDK4 antibody used in this study immunoprecipitated similar levels of CDK4 from all protein extracts analyzed i.e. from wild type, 'cyclin D1-only', 'cyclin D2-only' and 'cyclin D3only' embryos (Fig. 2A). Then, we performed in vitro kinase assays using $\mathrm{pRb}$ as a substrate. CDK4 precipitated from extracts of wild-type, 'cyclin D2-only' and 'cyclin D3-only' embryos had similar kinase activity, as judged by the phosphorylation of the exogenous pRb (Fig. 2B). Surprisingly, we did not detect CDK4 activity in extracts obtained from embryos expressing only cyclin D1 (Fig. 2B).

Our previous study showed that 'cyclin D2-only' and 'cyclin D3-only' embryos were able to develop until term. In contrary, 'cyclin D1-only' embryos failed to develop further than 16.5 day of embryonic development. Cyclin D1-only embryos died due to the failure of embryonic hematopoiesis, that at this stage of development occurs in embryonic liver (Ciemerych etal., 2002). Thus, it seemed possible that the low levels of CDK4 activity at 13.5 day of pregnancy might be caused by the impaired health of the mutant embryos. Therefore, we analyzed CDK4 activity in protein extracts of wild-type and 'cyclin D1-only' embryos obtained at earlier stages of development, i.e. at embryonic day 11.5. We also compared CDK4 activity detected in protein extracts from livers and "trunks" (remnants of embryo bodies that were left after liver removal). Protein extracts prepared from livers as well as from "trunks" of wild-type embryos displayed high CDK4 activity. However, we detected no CDK4 activity in protein extracts from livers or from "trunks" of "cyclin 
D1-only' embryos (Fig. 2C).

\section{Cyclin D-CDK4-p27kip1 complexes are present in 'single- cyclin' embryos}

p2 $7^{\mathrm{Kip} 1}$ and other members of the KIP/CIP protein family were shown to serve as inhibitors of CDK2 (Harper et al., 1993; Polyak et al., 1994; Toyoshima and Hunter, 1994; Lee et al., 1995; Soos et al., 1996) and CDK1-containing complexes (Nakayama et al., 2004; Pagano, 2004). Furthermore, it has been previously documented that these proteins do not inhibit the catalytic activity of CDK4 or CDK6, but serve as assembly factors for cyclin D-CDK complexes (Blain et al., 1997; La Baer et al., 1997; Cheng et al., 1999). Importantly, it was previously showed that in the absence of all D-type cyclins, CDK4 did not interact

A

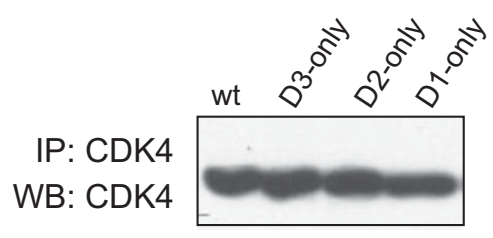

B

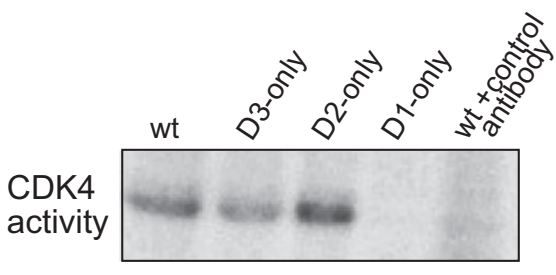

C

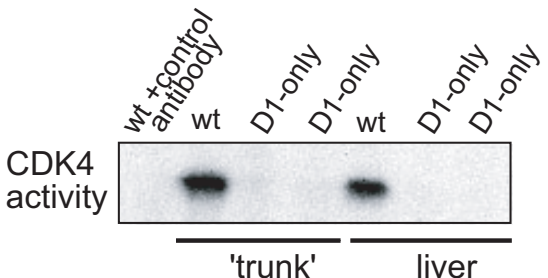

Fig. 2 (Left). Analysis of CDK4 activity. Protein extracts were prepared from E13.5 (A,B) and E11.5 (C) wild-type and 'single-cyclin' embryos. (A) CDK4 was immunoprecipitated (IP) and then detected by Western blotting (WB) using anti-CDK4 antibody. (B,C) CDK4 was immunoprecipitated and kinase assay was performed using recombinant $p R b$ as a substrate. For negative control, the wild-type protein extracts were subjected to immunoprecipitation with unrelated, anti-progesterone receptor antibody (wt + control antibody). (B) CDK4 - associated kinase activity in wild-type and 'single-cyclin' embryos. (C) CDK4 - associated kinase activity in "trunks" and livers isolated from wild-type and 'cyclin D1-only' embryos.

Fig. 3 (Right). Analysis of cyclin D-CDK4-p27 Kip1 complexes. Protein extracts were prepared from E13.5 wild-type and 'single-cyclin' embryos and subjected to immunoprecipitation (IP) and Western blotting (WB). (A) CDK4 and D-type cyclins were immunopreciptated from protein extracts from wild-type embryos, and immunoblotted with anti-CDK4 antibody. (B) CDK4 was immunoprecipitated from protein extracts from wild-type and 'single-cyclin' embryos, and immunoblotted with anti-CDK4 and anti-p27Kip1 antibody. (C) p27 $7^{K i p 1}$ was immunoprecipitated from protein extracts from wild-type embryos, and immunoblotted with anti-p2 $7^{K i p} 1$, and antibodies against individual D-type cyclin. (D) p2 $7^{\mathrm{Kip} 1}$ was immunoprecipitated from protein extracts from 'single-cyclin' embryos, and immunoblotted with antibodies against individual D-type cyclins. with p27 Kip1 (Hall et al., 1995; Kozar et al., 2004). Since the absence of CDK4 activity in protein extracts of 'cyclin D1-only' embryos might have been caused by the failure of cyclin D1 to associate with CDK4 and p27 ${ }^{\mathrm{Kip} 1}$, we examined the formation of these complexes in wild-type and 'single-cyclin' embryos at 13.5 of embryonic development. First, we immunoprecipitated cyclin D1, cyclin D2 or cyclin D3 from protein extracts of wild-type embryos, and immunoblotted with anti-CDK4 antibodies. We found that each of these D-cyclins associated with CDK4 (Fig. $3 A)$. We also immunoprecipitated CDK4 from protein extracts of wild-type and 'single-cyclin' embryos and found that CDK4 was able to bind p27 ${ }^{\text {Kip1 }}$ (Fig. 3B). Next, we demonstrated that in wildtype embryo extracts, the p27 ${ }^{\mathrm{Kip} 1}$ co-precipitated with each individual cyclin D (Fig. 3C). This interaction was also detected in
WB: CDK4

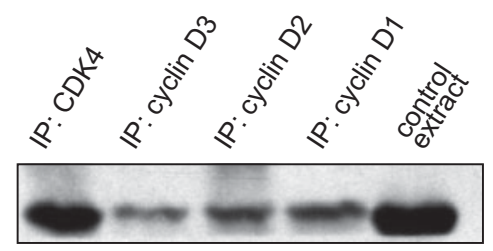

B

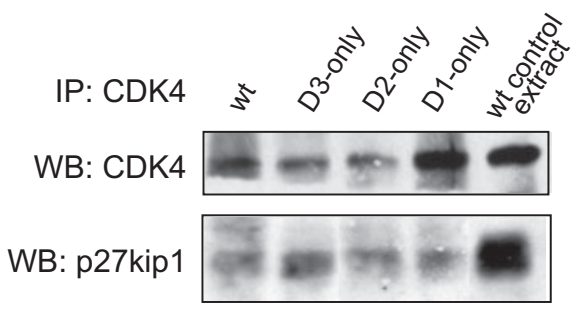

C
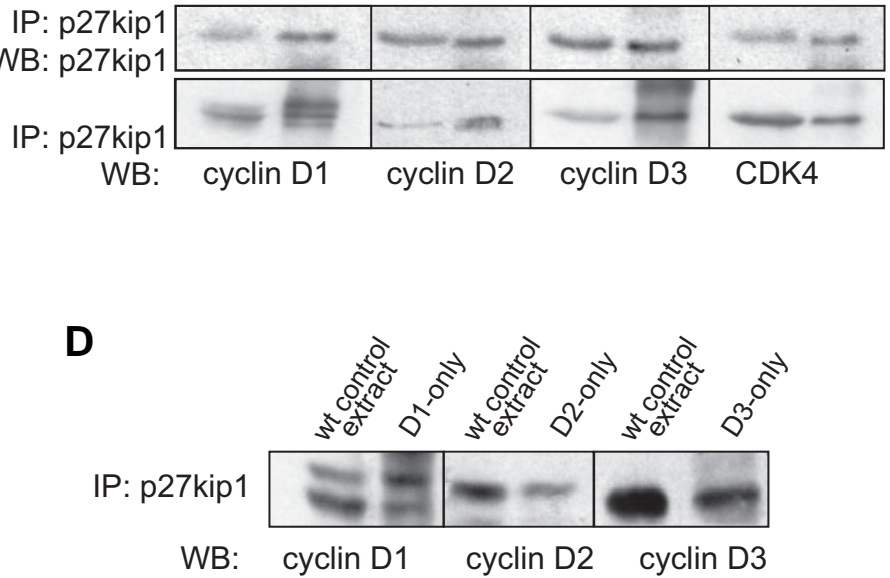
embryos expressing only cyclin D3 or only cyclin D2 and, importantly, embryos expressing only cyclin D1 (Fig. 3D). We concluded that at 13.5 day of embryonic development each of the Dtype cyclins was able to complex with CDK4 and with p27Kip1. Therefore, lack of CDK4 activity in protein extracts obtained from embryos expressing only cyclin D1 was not caused by the failure of complex formation.

\section{Expression of CDK4 and D-type cyclins in E13.5 mouse embryos}

Several lines of evidence indicated that D-type cyclins are differently expressed in various tissues and organs (Ravnik et al., 1995; Aguzzi et al., 1996; Robker and Richards; 1998; Ciemerych et al., 2002). In our previous studies we compared the levels of cyclin D1, D2 and D3 in protein extracts from different organs (hearts, kidneys, brains, spleens) dissected from 16.5 and 18.5 day embryos. These analyses confirmed that in wild-type embryos all three D-type cyclins were expressed in different tissues and organs (Ciemerych et al., 2002). Due to the limitation associated with the size of specific organs of 13.5 day embryo, we did not analyze D-type cyclin levels at this stage of development. Therefore, we now decided to examine expression pattern of three D-type cyclins and also their catalytic partner CDK4 in E13.5 embryos by in situ hybridization using radioactively labeled antisense probes (Fig. 4). These analyses revealed that in wildtype embryos mRNA encoding cyclin D1 was the least abundant.
Its highest expression was detected in retina and developing brain. Less intense signal was detected in liver. Cyclin D1 expression did not seem to be changed in 'cyclin D1-only' embryos as compared to wild-type control (Fig. 4). In contrast to this restricted pattern of cyclin D1 expression, mRNAs encoding cyclin D2 and cyclin D3 were broadly expressed in various tissues and organs. Cyclin D2 mRNA was highly expressed in the developing brain, skeleton (ribs), intestinal tract epithelium (stomach) and umbilical cord (Fig. 4). Cyclin D3 mRNA was highly expressed in developing liver and muscles, with lower levels in brain. Importantly, CDK4 mRNA was abundantly expressed within the tissues of E13.5 embryo (Fig. 4) Thus, it is possible that due to the limited expression of cyclin D1, the activity of cyclin D1-dependent kinase is very low in developing mouse embryo (see Fig. 2B), and therefore, it might be undetectable in protein extracts obtained at this stage of development.

\section{Discussion}

We previously generated 'single-cyclin' mice expressing only cyclin D1, cyclin D2 or cyclin D3 (Ciemerych et al., 2002). In this study we took advantage of these mice and studied the role of the individual D-type cyclins in activation of CDK4 kinase and phosphorylation of retinoblastoma protein during mouse embryo development. We observed that in protein extracts obtained from E13.5 embryos expressing only cyclin $\mathrm{D} 1$, pRb was present in its

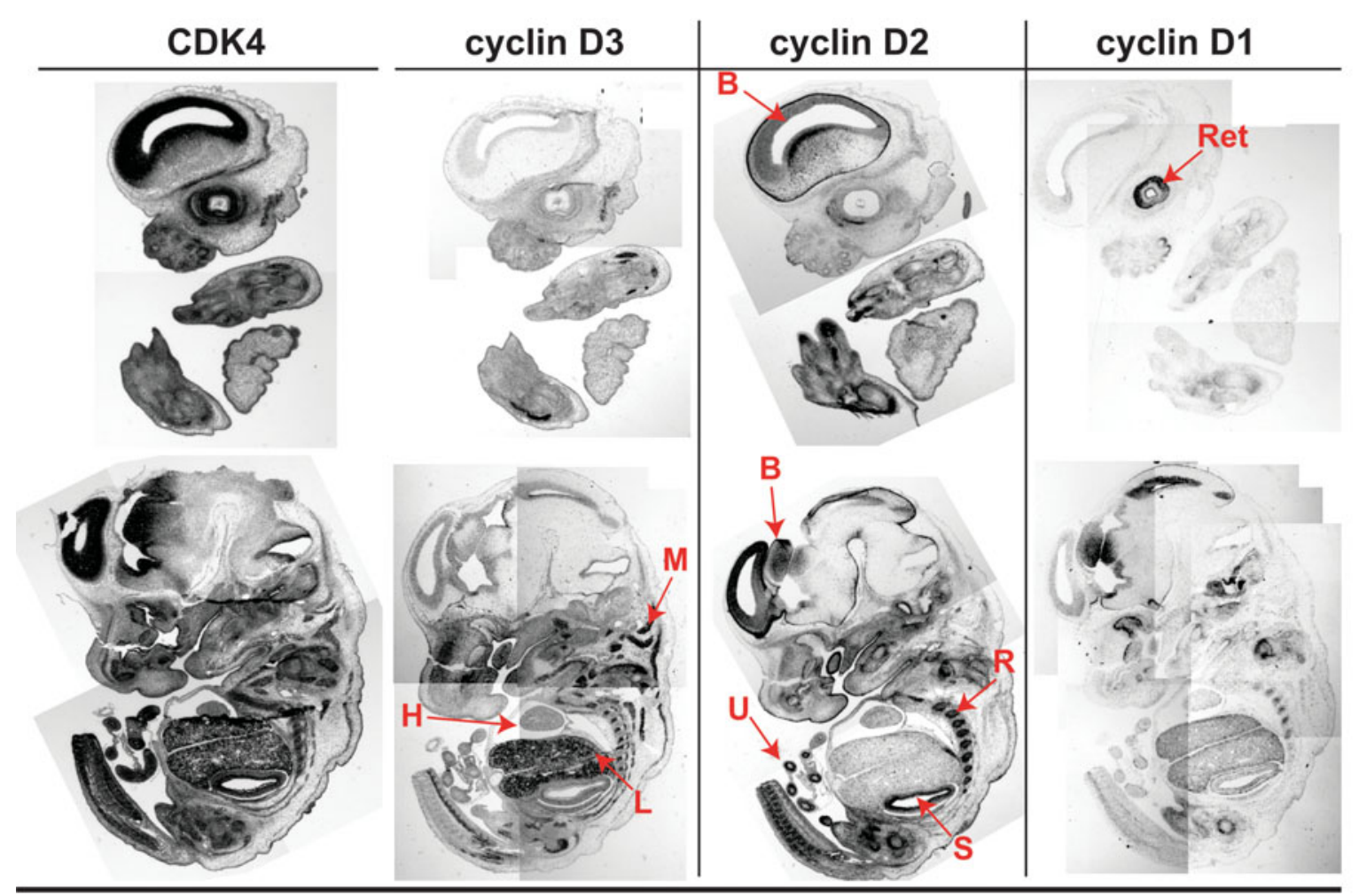

wild-type embryo

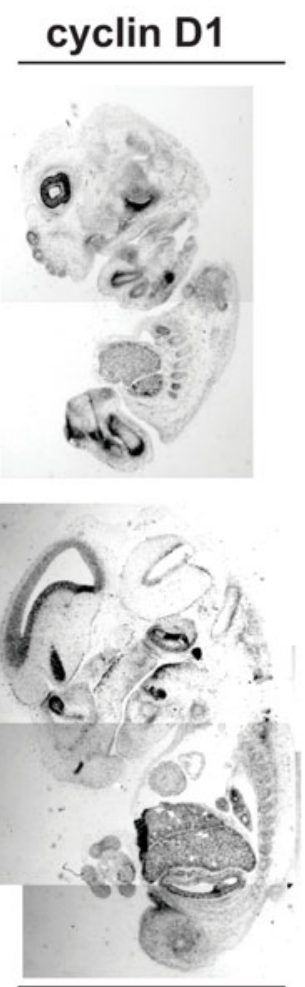

$\overline{\text { D1-only embryo }}$

Fig. 4. CDK4 and cyclin D expression in E13.5 mouse embryos. Sections of wild-type embryos were hybridized with riboprobes specific for CDK4, cyclin D1, cyclin D2 or cyclin D3. Sections of 'cyclin D1-only' embryos were hybridized with riboprobe specific for cyclin D1. Black color represents hybridization signal. $B$, brain; Ret, retina; $M$, muscle; $L$, liver; $R$, ribs; $U$, umbillical cord; $S$, stomach. 
hypophosphorylated form. Moreover, we detected CDK4-associated kinase activity in extracts of embryos expressing all three Dtype cyclins, as well as in "cyclin D2-only" and "cyclin D3-only" embryos, but not in "cyclin D1-only" embryos. These results suggested that cyclin D1-dependent CDK4 might not be efficiently activated during embryonic development. It also indicates that cyclin D1-dependent CDK4 activity is likely dispensable for development. This hypothesis was recently formally tested using 'knock-in' mice expressing mutated cyclin D1 that was unable to activate CDK 4 and CDK6 (D1KE/KE) (Landis et al., 2006). Importantly, lack of cyclin D1-associated CDK activity did not result in some of the defects that were previously observed in mice lacking cyclin D1 (D1/-). Unlike D1/- mice, D1 ${ }^{K E / K E}$ mice did not suffer from severe retinal hypoplasia or abnormalities in mammary epithelial lobuloalveolar development (Fantl et al., 1995, Landis et al., 2006, Sicinski et al., 1995). Interestingly, in cyclin D1-dependent tissues lack of cyclin D1 affects proper sequestration of p27kip1 allowing this inhibitor to block CDK2 activity and preventing normal proliferation. Ablation of $\mathrm{p} 27^{\mathrm{Kip} 1}$ rescued phenotype of $\mathrm{D} 1^{-}$ 1- mice indicating the role of D-type cyclins in sequestration of CDK inhibitors (Geng et al., 2001; Tong and Pollard, 2001). Importantly, mutated form of cyclin D1 present in D1 ${ }^{K E} / K E_{\text {tissues retains }}$ the ability to titrate p27kip 1 allowing normal CDK2 activation and cell cycle progression (Landis et al., 2006).

D-type cyclins were shown to be involved in regulation of different transcription factors, thus, it is possible that other, noncatalytic functions of cyclin D1 contribute to proper organogenesis (Coqueret, 2002). These other roles of cyclin D1 include activation of estrogen receptor (Neuman et al., 1997; Zwijsen et al., 1997), or repression of such transcription factors as androgen receptor (Knudsen et al., 1999), DMP1 (Hirai and Sherr, 1996; Inoue and Sherr, 1998), STAT3 (Bienvenu et al., 2001), C/EBP $\beta$ (Lamb et al., 2003), or Beta2/NeuroD (Ratineau et al., 2002). Cyclin D1 was also shown to affect function of MyoD (Skapek et al., 1995) and to serve as transcriptional co-factor of several other transcription factors (Coqueret, 2002). Cyclin D1 involvement in the regulation of transcription may be particularly important for differentiation decisions during embryonic development. For example STAT3 plays a crucial role in signaling during brain development (Fukuda and Taga, 2005), whereas Beta2/NeuroD was shown to control neurogenesis (Liu et al., 2000; Del Turco et al., 2004) and pancreatic development (Habener et al., 2005). Interestingly, it was shown that the lack of cyclin D1 or cyclin D2 compromises cerebellar development (Huard etal., 1999; Pogoriler et al., 2006). Moreover, development of pancreas also requires cyclin D1 (Kushner et al., 2005).

One of the steps required for CDK4 activation depends on association with cyclin $D$ and one of the members of KIP/CIP protein family such as p27kip1 (La Baer et al., 1997; Geng et al., 2001; Tong and Pollard, 2001). Analyses of protein extracts obtained from wild-type and 'single-cyclin' embryos showed that cyclin D1, CDK4 and p27 Kip1 were able to interact with each other. Thus, we concluded that lack of cyclin D1- dependent CDK4 activity could not be explained by the inability to form cyclin D1CDK4 complexes. However, we did not test if other molecular mechanisms necessary for CDK4 activation in cyclin D1-only cells, such as CDK phosphorylation catalyzed by CAK, or CDK dephosphorylation driven by CDC25 phosphatases proceed normally (Kaldis, 1999; Nigg, 2001). In vitroexperiments showed that in various cell lines, all D-type cyclins, including cyclin D1, can activate CDK4 and drive pRb phosphorylation. In some of these studies cyclin D1-associated kinase activity was detected in in vitro cultured mouse embryonic fibroblasts (Bagui et al., 2000; Sugimoto et al., 2002). Other investigations employed overexpression of cyclin D1 in mouse myeloid cells, Rat-2 fibroblasts (Matsushime et al., 1994), or mouse NIH3T3 cells (Matsushime et al., 1994; Cheng et al., 1998). Our findings raise a possibility that cyclin D1-dependent kinase activity may be regulated differently in cultured cells and during mouse embryo development.

Alternatively, our inability to detect CDK4 activity in protein extracts of 'cyclin D1-only' embryos may be also explained by low levels of this particular cyclin during embryonic development. We did not establish the cyclin D1 levels in different tissues and organs, but our in situ hybridization analyses revealed very restricted expression of cyclin D1, in contrast to wide-spread expression of cyclin D2 and D3. Therefore, it is possible that the low levels of CDK4 activity in protein extracts of embryos expressing only cyclin D1 could reflect the limited distribution of this cyclin.

The phenotype of 'cyclin D1-only' embryos closely resembled the phenotype of 'cyclin D-null' embryos (lacking all three D-type cyclins), consistent with limited contribution of cyclin D1-CDK4 to mouse development. Both mutants died at the similar stage i.e. 15.5-16.5 day of development, due to a severe anemia (Ciemerych et al., 2002; Kozar et al., 2004). Moreover, similar phenotype i.e. embryonic lethality due to anemia, was described for mouse embryos lacking functional genes encoding CDK4 and CDK6 $\left(\mathrm{CDK}^{-/-} \mathrm{CDK6}^{-/-}\right.$) (Malumbres et al., 2004). Therefore, we concluded that advanced stages of embryonic development can be reached in absence of cyclin D-CDK4/6 activities (Kozar and Sicinski, 2005). However, it has to be pointed out that at the later stages of development D-type cyclins and CDK4/6 are necessary for successful formation and proper function of different tissues and organs (for review see Ciemerych and Sicinski, 2005).

\section{Materials and Methods}

\section{'Single-cyclin' mice}

Cyclin D1/-, D2 $2^{-/-}$and D3-/- mice (Sicinski et al., 1995; Sicinski et al., 1996; Sicinska et al., 2003) were bred to generate double heterozygous $\left(\mathrm{D} 1^{+/-} \mathrm{D} 2^{+/-}, \mathrm{D}^{1+/-} \mathrm{D} 3^{+/-}, \mathrm{D} 2^{+/-} \mathrm{D}^{+/-}\right)$and heterozygous/knockout (D1 ${ }^{+/-} \mathrm{D} 2^{-/}$, $\left.\mathrm{D} 1^{+/-} \mathrm{D} 3^{-/-}, \mathrm{D} 2^{+/-} \mathrm{D} 3^{-/-}\right)$animals. These mice were then crossed yielding

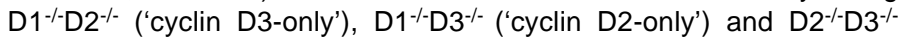
('cyclin D1-only') animals. Mice were genotyped by the PCR as described (Sicinski et al., 1995; Sicinski et al., 1996; Sicinska et al., 2003). Embryos were collected at day E11.5 and E13.5.

\section{Western blotting, immunoprecipitation and in vitro kinase assays}

Protein extracts were produced by homogenization and lysis of E11.5 embryonic tissues ("trunks" and livers) or whole E13.5 embryos as described previously (Carthon et al., 2005). Lysates were kept on ice for 30 minutes, microcentrifuged and stored at $-80^{\circ} \mathrm{C}$. Protein concentration was determined by using the Bio-Rad protein assay. $200 \mu \mathrm{g}$ of protein was subjected to Western-blot analysis and probed with antibodies against pRB (554136, BD Biosciences) or pRb Ser807/810 (Cell Signalling), as described previously (Ciemerych et al., 2002). For immunoprecipitation $100-200 \mu \mathrm{g}$ of protein was incubated with antibodies against CDK4 (C-22, Santa Cruz Biotechnology), or against p27kip1 (C-19, Santa Cruz Biotechnology) conjugated to agarose beads, subjected to Western-blot analysis and probed with the antibodies against cyclin D1 (Ab-3; NeoMarkers), cyclin D2 (M-20, Santa Cruz Biotechnology), cyclin D3 (C- 
16, Santa Cruz Biotechnology), CDK4 (C-22, Santa Cruz Biotechnology), p27 Kip1 (C-19, Santa Cruz Biotechnology). As the secondary antibodies, peroxidase-conjugated IgG (Jackson ImmunoResearch) was used, followed by enhanced chmiluminescence detection (Amersham Pharmacia). For in vitro kinase assays, $100 \mu \mathrm{g}$ of protein lysates was incubated with anti-CDK4 (C-22, Santa Cruz Biotechnology) conjugated to agarose beads. As a control, anti-progesterone receptor antibody (C-19, Santa Cruz Biotechnology) was used. Recombinant retinoblastoma protein (sc4112; Santa Cruz Biotechnology) was used as a substrate for CDK4. Kinase reactions were performed with $\left[\gamma^{-32} \mathrm{P}\right]$ ATP as described (Matsushime et al., 1994). Each analysis was repeated at least four times using protein extracts obtained from different embryos.

\section{In situ hybridization}

Embryos were collected at E13.5 and processed as described (Sicinski et al., 1995). Briefly, they were fixed for $24 \mathrm{~h}$ in $4 \%$ paraformaldehyde in PBS at $4{ }^{\circ} \mathrm{C}$. Next, they were dehydrated, embedded in paraplast, and $5 \mu \mathrm{m}$ thin saggital sections were obtained. cDNA encoding cyclin D1, D2, D3 (Sicinska et al., 2003, Sicinski et al., 1996, Sicinski et al., 1995) and CDK4 (gift from C.J. Sherr; Khatib et al., 1993) were used to synthesize $\alpha-\left[{ }^{35} \mathrm{~S}\right]$ thio-UTP-labeled riboprobes. Sections were hybridized with antisense riboprobes as described (Sicinski et al., 1995). Each hybridization was performed at least on three different embryos.

\section{Acknowledgements \\ The authors thank members of the Sicinski lab for help and advice. This work was supported by grants from the State Committee for Scientific Research (KBN) to MAC (3P04C 002 25) and R01 CA108420 and R01 CA83688 to PS. MAC is a recipient of L'Oreal for Women and Science Foundation. PS is a Scholar of the Leukemia \& Lymphoma Society.}

\section{References}

AGUZZI, A., KIESS, M., RUED, D. and HAMEL, P.A. (1996). Cyclins D1, D2 and D3 are expressed in distinct tissues during mouse embryogenesis. Transgenics2: 29-39.

BAGUI, T.K., JACKSON, R.J., AGRAWAL, D. and PLEDGER, W.J. (2000). Analysis of cyclin D3-cdk4 complexes in fibroblasts expressing and lacking p27(kip1) and p21(cip1). Mol Cell Bio/20: 8748-57.

BIENVENU, F., GASCAN, H. and COQUERET, O. (2001). Cyclin D1 represses stat3 activation through a cdk4-independent mechanism. J Biol Chem 276: 16840-7.

BLAIN, S.W., MONTALVO, E. and MASSAGUE, J. (1997). Differential interaction of the cyclin-dependent kinase (cdk) inhibitor p27kip1 with cyclin A-cdk2 and cyclin D2-cdk4. J Biol Chem 272: 25863-72.

CARTHON, B.C., NEUMANN, C.A., DAS, M., PAWLYK, B., LI, T., GENG, Y. and SICINSKI, P. (2005). Genetic replacement of cyclin D1 function in mouse development by cyclin D2. Mol Cell Bio/25: 1081-8.

CHENG, M., OLIVIER, P., DIEHL, J.A., FERO, M., ROUSSEL, M.F., ROBERTS, J.M. and SHERR, C.J. (1999). The p21cip1 and p27kip1 cdk 'inhibitors' are essential activators of cyclin D-dependent kinases in murine fibroblasts. Embo J18: 1571-1583.

CHENG, M., SEXL, V., SHERR, C.J. and ROUSSEL, M.F. (1998). Assembly of cyclin D-dependent kinase and titration of p27kip1 regulated by mitogenactivated protein kinase kinase (mek1). Proc Natl Acad Sci USA 95: 1091-6.

CIEMERYCH, M.A., KENNEY, A.M., SICINSKA, E., KALASZCZYNSKA, I., BRONSON, R.T., ROWITCH, D.H., GARDNER, H. and SICINSKI, P. (2002). Development of mice expressing a single D-type cyclin. Genes Dev 16: 327789.

CIEMERYCH, M.A. and SICINSKI, P. (2005). Cell cycle in mouse development. Oncogene 24: 2877-98.

COQUERET, O. (2002). Linking cyclins to transcriptional control. Gene 299: 35-55.

DEL TURCO, D., GEBHARDt, C., BURBACH, G.J., PLEASURE, S.J., LOWENSTEIN, D.H. and DELLER, T. (2004). Laminar organization of the mouse dentate gyrus: Insights from beta2/neuro D mutant mice. J Comp Neuro/
477: 81-95.

DIMOVA, D.K. and DYSON, N.J. (2005). The E2F transcriptional network: Old acquaintances with new faces. Oncogene 24: 2810-26.

FANTL, V., STAMP, G., ANDREWS, A., ROSEWELL, I. and DICKSON, C. (1995). Mice lacking cyclin D1 are small and show defects in eye and mammary gland development. Genes Dev 9: 2364-72.

FUKUDA, S. and TAGA, T. (2005). Cell fate determination regulated by a transcriptional signal network in the developing mouse brain. Anat Sci Int 80: 12-8.

GENG, Y., YU, Q., SICINSKA, E., DAS, M., BRONSON, R.T. and SICINSKI, P. (2001). Deletion of the p27kip1 gene restores normal development in cyclin D1deficient mice. Proc Nat/ Acad Sci USA 98: 194-9.

HABENER, J.F., KEMP, D.M. and THOMAS, M.K. (2005). Minireview: Transcriptional regulation in pancreatic development. Endocrinology 146: 1025-34.

HALL, M., BATES, S. and PETERS, G. (1995). Evidence for different modes of action of cyclin-dependent kinase inhibitors: $\mathrm{p} 15$ and p16 bind to kinases, p21 and p27 bind to cyclins. Oncogene 11: 1581-8.

HARPER, J.W., ADAMI, G.R., WEI, N., KEYOMARSI, K. and ELLEDGE, S.J. (1993). The p21 cdk-interacting protein cip1 is a potent inhibitor of G1 cyclindependent kinases. Cel/75: 805-16.

HIRAI, H. and SHERR, C.J. (1996). Interaction of d-type cyclins with a novel myblike transcription factor, DMP1. Mol Cel/ Biol16: 6457-67.

HUARD, J.M., FORSTER, C.C., CARTER, M.L., SICINSKI, P. and ROSS, M.E. (1999). Cerebellar histogenesis is disturbed in mice lacking cyclin D2. Development 126: 1927-35.

INOUE, K. and SHERR, C.J. (1998). Gene expression and cell cycle arrest mediated by transcription factor DMP1 is antagonized by d-type cyclins through a cyclin-dependent-kinase-independent mechanism. Mol Cel/ Bio/ 18: 1590600.

KALDIS, P. (1999). The cdk-activating kinase (CAK): From yeast to mammals. Cell Mol Life Sci55: 284-96.

KHATIB, Z.A., MATSUSHIME, H., VALENTINE, M., SHAPIRO, D.N., SHERR, C.J. and LOOK, A.T. (1993). Coamplification of the cdk4 gene with $\mathrm{mdm} 2$ and gli in human sarcomas. Cancer Res 53: 5535-41.

KNUDSEN, K.E., CAVENEE, W.K. and ARDEN, K.C. (1999). D-type cyclins complex with the androgen receptor and inhibit its transcriptional transactivation ability. Cancer Res 59: 2297-301.

KOZAR, K., CIEMERYCH, M.A., REBEL, V.I., SHIGEMATSU, H., ZAGOZDZON, A., SICINSKA, E., GENG, Y., YU, Q., BHATTACHARYA, S., BRONSON, R.T. et al. (2004). Mouse development and cell proliferation in the absence of $D$ cyclins. Cel/118: 477-91.

KOZAR, K. and SICINSKI, P. (2005). Cell cycle progression without cyclin D-cdk4 and cyclin D-cdk6 complexes. Cell Cycle 4: 388-91.

KUSHNER, J.A., CIEMERYCH, M.A., SICINSKA, E., WARTSCHOW, L.M., TETA, M., LONG, S.Y., SICINSKI, P. and WHITE, M.F. (2005). Cyclins D2 and D1 are essential for postnatal pancreatic beta-cell growth. Mo/ Cel/ Bio/25: 3752-62.

LABAER, J., GARRETT, M.D., STEVENSON, L.F., SLINGERLAND, J.M., SANDHU, C., CHOU, H.S., FATTAEY, A. and HARLOW, E. (1997). New functional activities for the p21 family of cdk inhibitors. Genes Dev 11: 847-62.

LAMB, J., RAMASWAMY, S., FORD, H.L., CONTRERAS, B., MARTINEZ, R.V., KITTRELL, F.S., ZAHNOW, C.A., PATTERSON, N., GOLUB, T.R. and EWEN, M.E. (2003). A mechanism of cyclin D1 action encoded in the patterns of gene expression in human cancer. Cel/114: 323-34.

LANDIS, M.W., PAWLYK, B.S., LI, T., SICINSKI, P. and HINDS, P.W. (2006). Cyclin D1-dependent kinase activity in murine development and mammary tumorigenesis. Cancer Cel/9: 13-22.

LEE, M.H., REYNISDOTTIR, I. and MASSAGUE, J. (1995). Cloning of p57kip2, a cyclin-dependent kinase inhibitor with unique domain structure and tissue distribution. Genes Dev 9: 639-49.

LIU, M., PLEASURE, S.J., COLLINS, A.E., NOEBELS, J.L., NAYA, F.J., TSAI, M.J. and LOWENSTEIN, D.H. (2000). Loss of beta2/neuro D leads to malformation of the dentate gyrus and epilepsy. Proc Nat/ Acad Sci USA 97: 865-70.

MALUMBRES, M., SOTILLO, R., SANTAMARIA, D., GALAN, J., CEREZO, A., ORTEGA, S., DUBUS, P. and BARBACID, M. (2004). Mammalian cells cycle without the d-type cyclin-dependent kinases cdk4 and cdk6. Cel/118: 493-504.

MATSUSHIME, H., QUELLE, D.E., SHURTLEFF, S.A., SHIBUYA, M., SHERR, 
C.J. and KATO, J.Y. (1994). D-type cyclin-dependent kinase activity in mammalian cells. Mol Cel/ Bio/14: 2066-76.

MATSUSHIME, H., ROUSSEL, M.F., ASHMUN, R.A. and SHERR, C.J. (1991). Colony-stimulating factor 1 regulates novel cyclins during the $\mathrm{G} 1$ phase of the cell cycle. Cel/65: 701-13.

NAKAYAMA, K., NAGAHAMA, H., MINAMISHIMA, Y.A., MIYAKE, S., ISHIDA, N., HATAKEYAMA, S., KITAGAWA, M., IEMURA, S., NATSUME, T. and NAKAYAMA, K.I. (2004). Skp2-mediated degradation of p27 regulates progression into mitosis. Dev Cel/6: 661-72.

NEUMAN, E., LADHA, M.H., LIN, N., UPTON, T.M., MILLER, S.J., DI RENZO, J., PESTELL, R.G., HINDS, P.W., DOWDY, S.F., BROWN, M. et al. (1997). Cyclin D1 stimulation of estrogen receptor transcriptional activity independent of cdk4. Mol Cell Biol17: 5338-47.

NIGG, E.A. (2001). Cell cycle regulation by protein kinases and phosphatases. Ernst Schering Res Found Workshop19-46.

PAGANO, M. (2004). Control of DNA synthesis and mitosis by the Skp2-p27-cdk1/ 2 axis. $\mathrm{Mol} \mathrm{Ce} / / 14:$ 414-6.

POGORILER, J., MILLEN, K., UTSET, M. and DU, W. (2006). Loss of cyclin D1 impairs cerebellar development and suppresses medulloblastoma formation. Development 133: 3929-37.

POLYAK, K., LEE, M.H., ERDJUMENT-BROMAGE, H., KOFF, A., ROBERTS, J.M., TEMPST, P. and MASSAGUE, J. (1994). Cloning of p27kip1, a cyclindependent kinase inhibitor and a potential mediator of extracellular antimitogenic signals. Cel/78: 59-66.

RATINEAU, C., PETRY, M.W., MUTOH, H. and LEITER, A.B. (2002). Cyclin D1 represses the basic helix-loop-helix transcription factor, beta2/neuroD. J Bio/ Chem 277: 8847-53.

RAVNIK, S.E., RHEE, K. and WOLGEMUTH, D.J. (1995). Distinct patterns of expression of the D-type cyclins during testicular development in the mouse. Dev Genet 16: 171-8.

ROBKER, R.L. and RICHARDS, J.S. (1998). Hormone-induced proliferation and differentiation of granulosa cells: A coordinated balance of the cell cycle regulators cyclin D2 and p27kip1. Mol Endocrino/12: 924-40.

SICINSKA, E., AIFANTIS, I., LE CAM, L., SWAT, W., BOROWSKI, C., YU, Q., FERRANDO, A.A., LEVIN, S.D., GENG, Y., VON BOEHMER, H. et al. (2003).
Requirement for cyclin D3 in lymphocyte development and t cell leukemias. Cancer Cel/4: 451-61.

SICINSKI, P., DONAHER, J.L., GENG, Y., PARKER, S.B., GARDNER, H., PARK, M.Y., ROBKER, R.L., RICHARDS, J.S., MCGINNIS, L.K., BIGGERS, J.D. et al. (1996). Cyclin D2 is an FSH-responsive gene involved in gonadal cell proliferation and oncogenesis. Nature 384: p470-4.

SICINSKI, P., DONAHER, J.L., PARKER, S.B., LI, T., FAZELI, A., GARDNER, H., HASLAM, S.Z., BRONSON, R.T., ELLEDGE, S.J. and WEINBERG, R.A. (1995). Cyclin D1 provides a link between development and oncogenesis in the retina and breast. Cel/82: 621-30.

SKAPEK, S.X., RHEE, J., SPICER, D.B. and LASSAR, A.B. (1995). Inhibition of myogenic differentiation in proliferating myoblasts by cyclin D1-dependent kinase. Science 267: 1022-4.

SOOS, T.J., KIYOKAWA, H., YAN, J.S., RUBIN, M.S., GIORDANO, A., DEBLASIO, A., BOTTEGA, S., WONG, B., MENDELSOHN, J. and KOFF, A. (1996). Formation of p27-cdk complexes during the human mitotic cell cycle. Cell Growth Differ 7: 135-46.

SUGIMOTO, M., MARTIN, N., WILKS, D.P., TAMAI, K., HUOT, T.J., PANTOJA, C., OKUMURA, K., SERRANO, M. and HARA, E. (2002). Activation of cyclin D1kinase in murine fibroblasts lacking both p21(cip1) and p27(kip1). Oncogene 21: 8067-74.

TONG, W. and POLLARD, J.W. (2001). Genetic evidence for the interactions of cyclin D1 and p27(kip1) in mice. Mol Cel/ Bio/21: 1319-28.

TOYOSHIMA, H. and HUNTER, T. (1994). p27, a novel inhibitor of G1 cyclin-cdk protein kinase activity, is related to p21. Cel/78: 67-74.

VIDAL, A. and KOFF, A. (2000). Cell-cycle inhibitors: Three families united by a common cause. Gene 247: 1-15.

YU, Q., CIEMERYCH, M.A. and SICINSKI, P. (2005). Ras and myc can drive oncogenic cell proliferation through individual D-cyclins. Oncogene24: 7114-9.

ZARKOWSKA, T. and MITTNACHT, S. (1997). Differential phosphorylation of the retinoblastoma protein by $\mathrm{G} 1 / \mathrm{S}$ cyclin-dependent kinases. J Biol Chem 272: 12738-46.

ZWIJSEN, R.M., WIENTJENS, E., KLOMPMAKER, R., VAN DER SMAN, J., BERNARDS, R. and MICHALIDES, R.J. (1997). Cdk-independent activation of estrogen receptor by cyclin D1. Ce//88: 405-15. 


\section{Related, previously published Int. J. Dev. Biol. articles}

See our recent Special Issue Developmental Biology in Poland edited by Kloc, Maleszewski and Tarkowski at: http://www.ijdb.ehu.es/web/contents.php?vol=52\&issue=2-3

See our Special Issue Mammalian Reproduction \& Development in honor of Anne McLaren and edited by Brigid Hogan at: http://www.ijdb.ehu.es/web/contents. php?vol=45\&issue $=3$

OI-KIP, a cyclin dependent kinase inhibitor, is expressed in developing and adult brain of the Medaka (Oryzias latipes)

EMC Suarez, V Nguyen, JS Joly, F Bourrat

Int. J. Dev. Biol. (2001) 45: S71-S72

Expression of the E2F family of transcription factors during murine development.

J C Kusek, R M Greene, P Nugent and M M Pisano, Int. J. Dev. Biol. (2000) 44: 267-277

p34(cdc2) and mitotic cyclin expression in the developing quail neuroretina.

X Espanel, A Kastner, O Stettler, B Tavitian, G Brun and G Gillet Int. J. Dev. Biol. (1997) 41: 469-476

Correlation of ploidy and cyclin B1, P34cdc2 and PCNA expression in $\mathrm{F} 9$ teratocarcinoma cells.

A Baroja, C de la Hoz, J M De Gandarias and J Arechaga

Int. J. Dev. Biol. (1996) 40: S277-S278

Cell reproduction: induction of M-phase events by cyclin-dependent cdc2 kinase.

T Kishimoto

Int. J. Dev. Biol. (1994) 38: 185-191

Two proto-oncogenes that play dual roles in embryonal cell growth and differentiation.

E D Adamson, Int. J. Dev. Biol. (1993) 37: 111-116

Growth factors and proto-oncogenes in early mouse embryogenesis and tumorigenesis.

K Pavelic, N P Slaus and R Spaventi, Int. J. Dev. Biol. (1991) 35: 09214

Genes and mechanisms involved in early embryonic development in Xenopus laevis.

M Méchali, G Almouzni, Y Andéol, J Moreau, S Vriz, M Leibovici, J Hourdry, J Géraudie, T Soussi and M Gusse, Int. J. Dev. Biol. (1990) 34: $51-59$

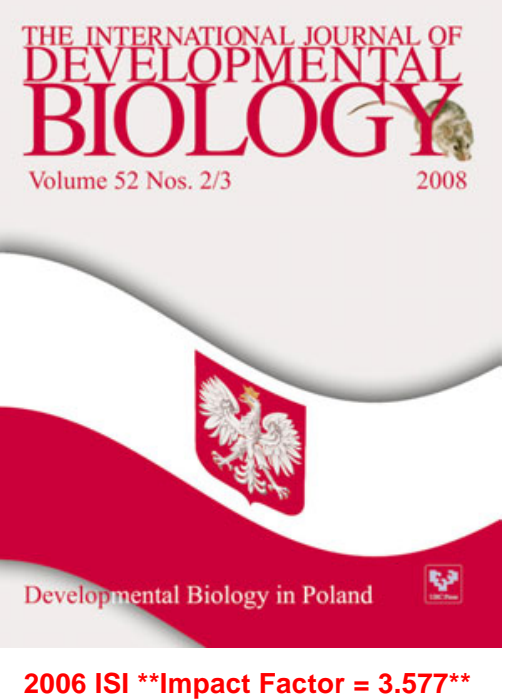

2006 ISI ${ }^{* *}$ Impact Factor $=3.577^{\star *}$

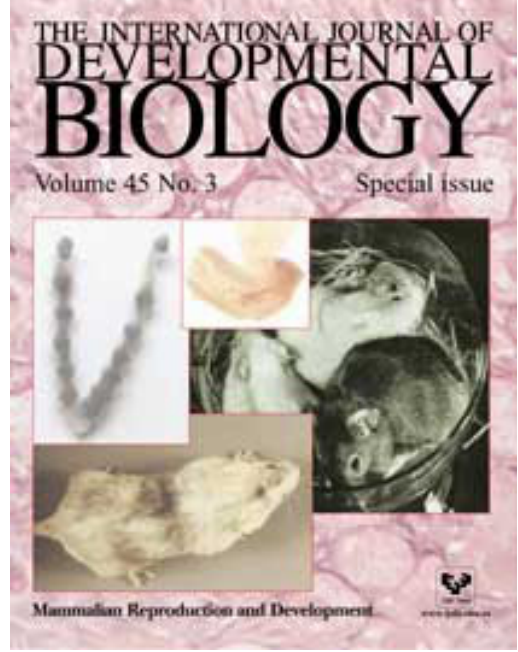

